\title{
TECCIENCLA
}

\section{Comparison of thermal solar collector technologies and their applications}

\section{Comparación de tecnologías de concentradores solares térmicos y sus aplicaciones}

\author{
Alexander Alarcón Villamil ${ }^{1}$, Jairo Eduardo Hortúa ${ }^{2}$, Andrea López ${ }^{3}$. \\ ${ }^{1}$ Universidad Distrital Francisco José de Caldas, Bogotá, Colombia, jalarcon@ udistrital.edu.co \\ ${ }^{2}$ Universidad Distrital Francisco José de Caldas, Bogotá, Colombia, ing.jairohortua@ gmail.com \\ ${ }^{3}$ Universidad Distrital Francisco José de Caldas, Bogotá, Colombia, Andrea_lopgo@ hotmail.com
}

\begin{abstract}
This paper presents the operation of different thermal solar collector technologies and their main characteristics. It starts by providing a brief description of the importance of using solar collectors as an alternative to reduce the environmental impact caused by the production of non-renewable sources like coal and oil. Subsequently, it focuses on each solar concentrator technology and finishes with a theoretical analysis hub application in different industrial processes.
\end{abstract}

Keywords: Direct solar radiation, energy, solar collectors, steam, temperature

\section{Resumen}

En este artículo se hace un análisis y comparación del funcionamiento de las diferentes clases de concentradores solares térmicos y sus principales características. Inicialmente, se hace una breve descripción de la importancia y el uso que actualmente se da a los concentradores solares como dispositivos de captación de energía solar térmica, teniendo en cuenta aspectos como la geometría y tamaño de los dispositivos, así como la radiación solar incidente. Adicionalmente, se analiza el impacto que su uso tendría en el medio ambiente gracias a la reducción en la cantidad de emisiones de gases contaminantes producidas por fuentes de generación de energía convencionales a base de carbón y petróleo. Posteriormente, se presentan cada una de las tecnologías de concentradores solares, y se finaliza realizando un análisis teórico de las aplicaciones de los concentradores en diferentes procesos de la industria.

Palabras clave: Concentradores solares, energía, radiación solar directa, temperatura, vapor

\section{Introduction}

Global energy consumption grows rapidly due to factors like population increase and technological development, increasing energy production requirements in its different forms, with electric energy and thermal energy having the highest demand. To meet these requirements, it is indispensable to use fossil fuels like coal, oil, and natural gas, but these generate negative effects because of the emission of residues and contaminating gases onto the environment, as well because of their high costs. Solar collectors offer a sustainable energy solution given that they permit capturing and using thermal energy from the sun, thus, using the great energy potential it offers us. This technology provides viable and sustainable options over time, which undoubtedly will be of great importance in the near future, which is why there is a need to identify and implement new energy sources capable of providing energy sustainability in the mid- or long-term [1]. Additionally, it helps to reduce the environmental impact caused by increased greenhouse gases like carbon dioxide $\left(\mathrm{CO}_{2}\right)$, sulfur dioxide $\left(\mathrm{SO}_{2}\right)$ and nitrogen oxide (NOx), which are triggering climate change.

The sun, as main source of light and heat for the earth, is considered an inexhaustible resource of energy, of easy access, free, clean, and renewable; from which it is possible to obtain direct benefits through systems capable of 


\section{TECCIENCIA}

transforming the direct solar radiation into other types of useful energy to then be used in industrial processes or in small applications for the home.

\section{Thermal solar concentrators}

These are devices that permit focusing radiation from the sun on a reduced area (focus), to concentrate thermal energy and light to easily use it with devices like Stirling motors, heating systems, solar kitchens, vapor turbines, or photovoltaic cells among other devices that operate with thermal energy or with the visible radiation from the sun. These devices permit direct use of the energy obtained or its transformation into another type of useful energy [1] [2] [3]

The concentrator is a device constructed with a highreflectance material, which permits focusing radiation components released por the sun (visible radiation, infrared and ultraviolet rays) to avail of and use the energy contained in these signals. For their correct functioning, these must always be aimed directly at the sun because they require direct radiation to function, which is why they must use a device that permits tracking the sun's trajectory during the day. All the concentrators have the same operating principle, but present differences regarding geometry, amount of energy concentrated, and how the energy is used.

In most cases, the thermal energy obtained is used to generate vapor with water or alcohol and propel vapor turbines with which energy is produced; there is also the option of storing saline solutions or synthetic oils at high temperatures to later use this energy (when there is no direct radiation or at night).

Structurally, solar concentrators comprise three necessary elements for their functioning, which are mentioned ahead:

- Receptor or Absorber: System element that concentrates the radiation that will then be transformed into another type of useful energy. It is found on the device focus when working with spherical or cylindrical geometries.

- Concentrator or optical device: Surface that reflects or sends to the receptor the rays released by the sun that reach the concentrator's surface. The amount of energy received depends on the concentrator's surface area.

- Solar tracking system: Control device that based on a system of equations or on a system of sensors, permits detecting the sun's position during each instant of time and guides or positions the concentrator directly toward the sun by using a system of motors along with a system of gears or pulleys.

\subsection{Classification de thermal solar concentrators}

Solar collectors can be classified depending on their geometric configuration or on the temperature obtained by the working fluid after gaining heat. According to their geometric configuration they can be flat solar collectors and concentrating solar collectors.

According to the temperature, they are classified according to the range of temperatures reached by the working fluid, which in turn depends on the type of application for which the device is required. Table 1 indicates how these are classified according to the temperature reached:

Table 1: Classification of collectors according to the temperature obtained by the working fluid

\begin{tabular}{|c|c|}
\hline Solar collector & Temperature $\left({ }^{\circ} \mathbf{C}\right)$ \\
\hline Very low temperature & 10 to 25 \\
\hline Low temperature & 25 to 50 \\
\hline Medium temperature & 60 to 130 \\
\hline High temperature & 130 to 600 \\
\hline Very high temperature & Over 600 \\
\hline
\end{tabular}

Usually, very low and low temperature collectors are used for heating devices like water heaters and solar kitchens. Collectors of medium, high, and very high temperature are used to generate electric energy and for activities that require high temperatures like incineration of hazardous wastes.

\subsubsection{Parabolic cylindrical solar collector}

Parabolic cylindrical shaped collectors permit capturing direct radiation from the sun along a semi-cylindrical or parabolic structure placed horizontally, which has a sensor receptor tube located on the focal line of the parable along the structure (Figure 1) [1] [2]. Within this sensor tube circulates the fluid that absorbs the thermal energy obtained heating until reaching the desired temperature. Temperature in the fluid increases as it goes through the pipes. This technology is used in applications whose range of temperature is between 125 and $400{ }^{\circ} \mathrm{C}$. Usually, it is used in electric power generation facilities with large power capacity.

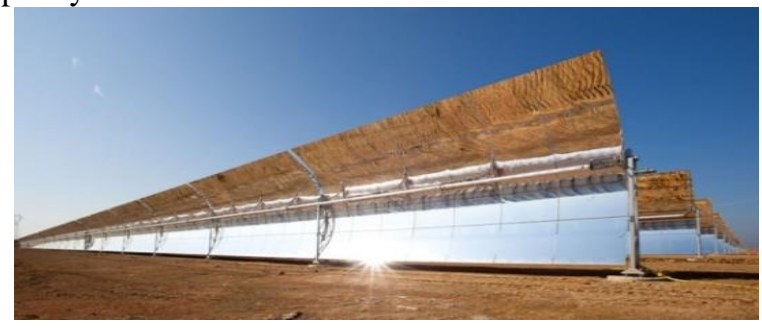

Figure 1. Parabolic cylindrical collector [4] 


\section{TECCIENCIA}

The type of working fluid used in this type of collector is usually demineralized water or ethylene glycol. In cases where the temperature exceeds $200{ }^{\circ} \mathrm{C}$, synthetic oils are used because they present higher boiling temperatures.

The hot fluid is taken to a heat exchanger where thermal energy is used to generate water vapor, which propels a vapor turbine connected to an electric generator.

\subsubsection{Parabolic dish-type collector}

The parabolic dish-type collector has a hemispherical surface that reflects the radiation from the sun onto a reduced area located on the system's focal point, where it is located on the receptor. Usually, it is used for temperatures between 130 and $600{ }^{\circ} \mathrm{C}$; however, it depends on the device's concentration ratio, defined as the relationship between the collector's surface area "Sc" and the receptor area "Sr". The higher the collector's Sc/Sr ratio, the higher the temperature reached in the receptor. It is used for electric power generation and for devices requiring high temperatures like furnaces to incinerate hazardous wastes. The system is basically comprised of a collector, a heat exchanger (receptor), and a solar tracking system that aims the collector directly at the sun during the day.

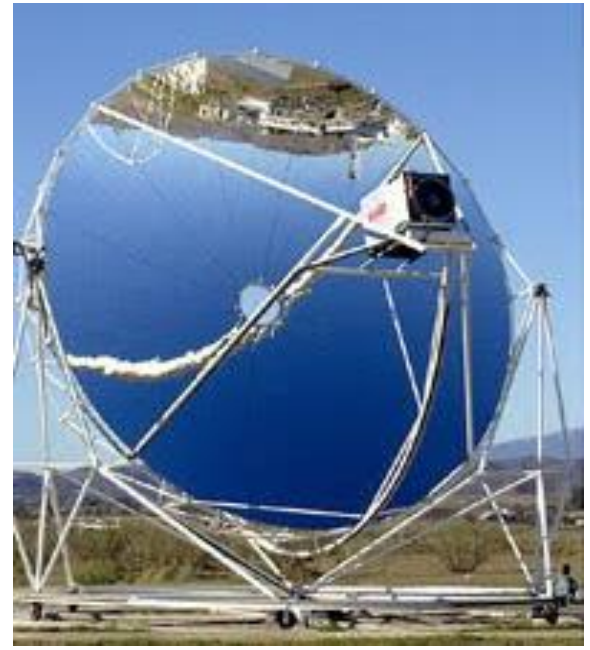

Figure 2. Parabolic dish type collector. [5]

Electric energy generation systems based on this technology use a Stirling type motor in the system's receptor [3] [6]. Este uses la thermal energy to propel el motor y el electric generator, integrated as a single device, as seen in Figure 2. In other versions, energy is used to generate water vapor that is used to propel a vapor turbine and a generator.

The dish structure permits tracking the sun's trajectory during the day. Generation systems based on this technology are currently constructed for powers from 3 to $25 \mathrm{~kW}$ for each collector, and it is possible to integrate several units to achieve medium power (MW) and high power (GW) projects, according to requirements or needs and the availability of the solar resource.

\subsubsection{Solar receptor systems or Central tower}

This comprises a group of heliostats (flat reflectors) aligned in circular manner. A tower is located in the center of the circumference, which captures the radiation reflected by the heliostats. The thermal energy captured is stored by using a salt-based fluid or with synthetic oils capable of withstanding very high temperatures. The fluid can be stored in a thermal condenser for later use or it can be brought directly to a heat exchanger where vapor is produced to propel a turbine and a generator as done with parabolic cylindrical collectors. The thermal condenser is a storage device where the fluid at high temperatures is deposited and which significantly reduces energy losses, given that it minimizes heat exchange with the environment because of the thermal isolation with which it was designed [3] [2] [7]

One of the advantages offered by this system against the rest is that it permits storing part of the energy obtained during the day for later use, during night hours or during days with low levels of solar radiation (Figure 3).

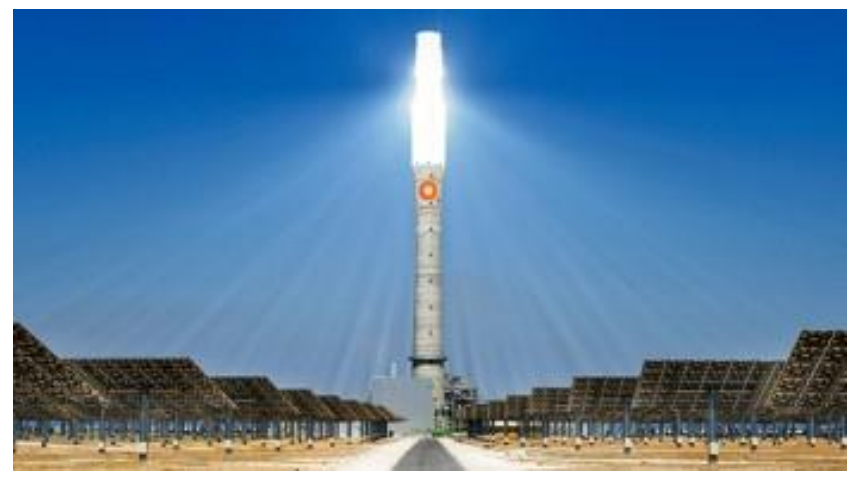

Figure 3. Central tower system and heliostat [8]

This technology is being implemented to construct large power capacity thermo solar plants in which a support system is also required.

Central tower systems have a great potential to reduce electricity costs in the mid-term compared to the technology of parabolic cylindrical collectors, given that they permit integration of thermal cycles.

\subsubsection{Linear Fresnel collector systems (LFR)}

This system is made up of a set of almost-flat reflectors, which concentrate solar radiation in high inverted receptors. As with parabolic cylindrical systems, a fluid is used to capture thermal energy reaching the system's receptor. 


\section{TECCIENCIA}

Unlike cylindrical collectors, this system uses a single receptor that captures the radiation reflected by several flat reflectors. This system permits increasing efficiency and reducing installation costs compared to cylindrical collectors (Figure 4).

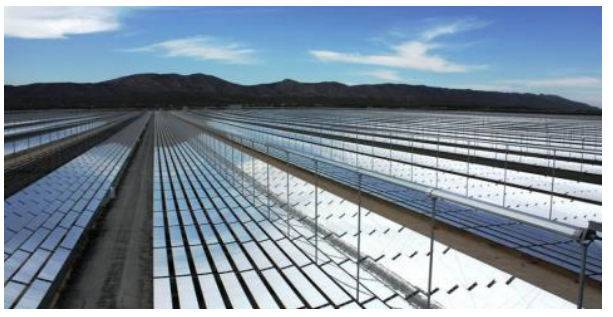

Figure 4. Linear Fresnel collector systems [9]

\section{Advantages and disadvantages of thermo solar technologies}

Table 2 presents the advantages and disadvantages of thermo solar technologies, bearing in mind relevant aspects like their operating temperature, efficiency, materials for their construction, storage capacity, among others.

Table 2: Advantages and disadvantages of thermo solar technologies

\begin{tabular}{|c|c|c|}
\hline Technology & Advantages & Disadvantages \\
\hline Parabolic cylinder & $\begin{array}{c}\text {-Potential operating temperature to } 500{ }^{\circ} \mathrm{C}\left(400{ }^{\circ} \mathrm{C} \text { tested commercially). }\right. \\
\text { • Net annual efficiency of the plant's proven performance of } 14 \% \text { (solar } \\
\text { radiation at net electric power). } \\
\text { •Investment y operational costs tested commercially. } \\
\cdot \text { Modularity and good use of terrain. } \\
\bullet \text { Lower demand for materials. } \\
\cdot \text { Hybrid concept tested with conventional thermal systems. } \\
\cdot \text { Storage capacity according los installation requirements. }\end{array}$ & $\begin{array}{l}\text { - Use of oil-based thermal transference } \\
\text { medium currently restricts operation } \\
\text { temperatures to } 400^{\circ} \mathrm{C} \text {, which is why only } \\
\text { moderate vapor quality is obtained. }\end{array}$ \\
\hline Central receptor & $\begin{array}{l}\text {-Potential operating temperature over } 1000{ }^{\circ} \mathrm{C}\left(565{ }^{\circ} \mathrm{C} \text { tested at } 10-\mathrm{MW}\right. \\
\text { scale). } \\
\qquad \text { Storage at high temperatures. } \\
\text { - Possible hybrid operation with conventional thermal systems. } \\
\text { - Best for dry refrigeration than the channel type and Fresnel type } \\
\text { collectors. } \\
\cdot \text { Better options to use in places not flat. }\end{array}$ & $\begin{array}{l}\text { •Foreseen annual performance values, } \\
\text { investment costs, and its operation need } \\
\text { tests at greater scale in commercial } \\
\text { operations. }\end{array}$ \\
\hline Parabolic dish & $\begin{array}{c}\text { - Very high conversion efficiencies, solar peak conversion at net } \\
\text { electricity of over } 30 \% \\
\bullet \text { Modularity } \\
\text { - Operational experience of first demo projects. } \\
\text { - Easy manufacture and series production of pieces available. } \\
\text { - Water not required to refrigerate the cycle }\end{array}$ & $\begin{array}{l}\text { - Does not permit storage of thermal energy } \\
\text { because it makes conversion directly. } \\
\text {-Costs of series production in verification } \\
\text { stages. } \\
\text {-Hybrid receptors still in R\&D process. }\end{array}$ \\
\hline Fresnel linear & $\begin{array}{l}\text { •Flat mirrors can be acquired with lower production costs. } \\
\text {-Possible hybrid operation with conventional thermal systems. } \\
\text {-Offers higher efficiency than parabolic channel systems. } \\
\text { •Permits reducing installation costs. }\end{array}$ & $\begin{array}{l}\text { - Recent market entry, only small } \\
\text { operational projects. } \\
\text { - Currently, in test stage. } \\
\text {-Few installations exist where this } \\
\text { technology has been implemented. }\end{array}$ \\
\hline
\end{tabular}

\section{Applications of thermal solar collectors}

Thermal solar collectors are used in a vast number of applications, given the benefits they bring to the environment and reduced energy consumption in numerous industrial processes and homes. The following present the main applications of these thermo solar elements.

\subsection{Solar drying}

Drying of agricultural and industrial products requires constant hot air to eliminate humidity. Via dish-type solar collectors, heat is produced that is circulated through the crops, fruits, or products, eliminating water on them. This system offers advantages with respect to others, given that the product remains free of dirt, dust, and its flavor and texture are maintained. In addition to the aforementioned, energy consumption is reduced to a minimum. In agriculture, it is used to dry fruits, vegetables, species, and 


\section{TECCIENCLA}

flowers. In industry, it is used to dry tea, coffee, rubber, cotton, thread, leather, and textiles.

\subsection{Environmental heating}

The environmental heating system is used in lowtemperature zones with very good solar radiation. In these systems, solar collectors are employed to heat a thermal fluid, which transfers its heat through a heat exchanger. This air is circulated through open spaces, with which a constant temperature is maintained, reducing electric energy consumption.

\subsection{Solar incineration}

By using solar collectors, it is possible to easily manage large amounts of waste water with profit, reaching temperatures of $1000{ }^{\circ} \mathrm{C}$, providing a non-contaminating elimination system to evaporate 10,000 liters or more of waste liquids from industrial processing units (Figure 5).

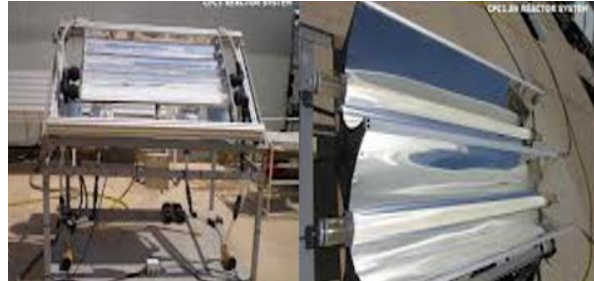

Figure 5. Waste water evaporation system. [10]

Figure 5 shows the waste water evaporation system installed in India, which permits incineration of hazardous waste liquids from pharmaceutical industries, hospitals, and processing plants [11] [12]

\subsection{Solar water heaters}

Solar water heaters are photo-thermal systems capable of using the sun's thermal energy to heat water without using any type of fuel. These comprise a flat solar collector, which captures the sun's energy and transfers it to the water; thermo-tank where the hot water is stored; and a tubing system to circulate the water (Figure 6).
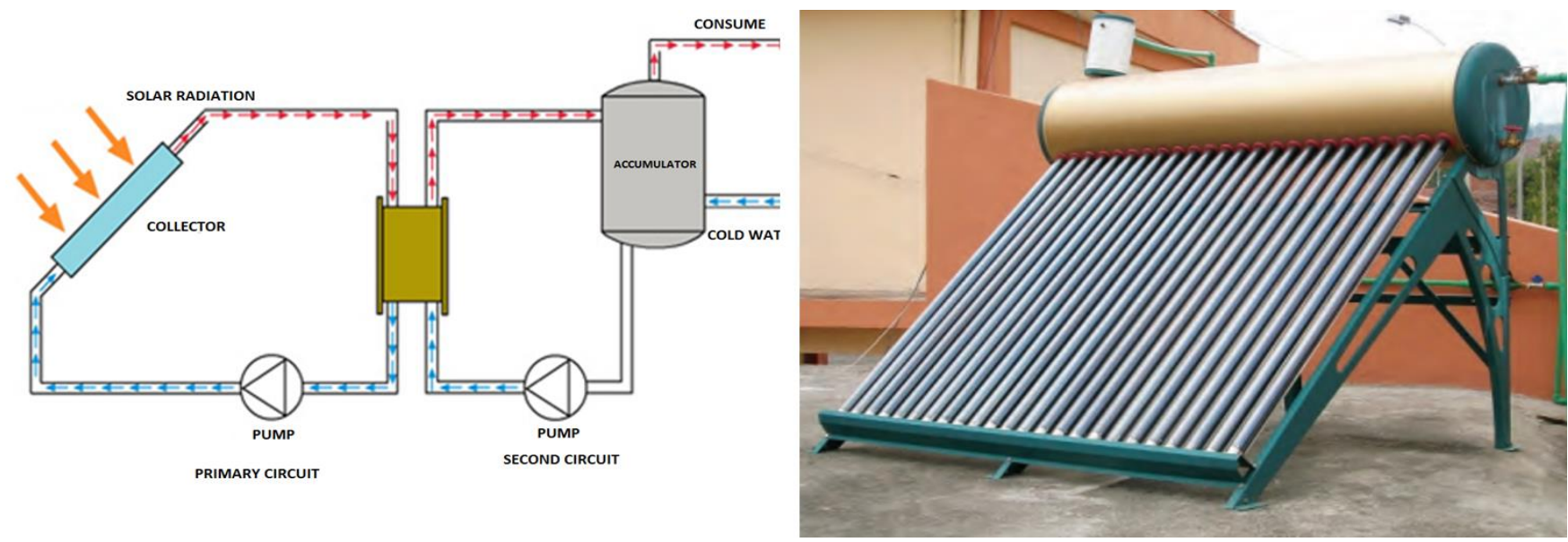

Figure 6. Scheme for solar water heater [13]

\subsection{Paper industry}

These industries use fields of collectors to heat water and produce vapor used in paper drying (Figure 7).

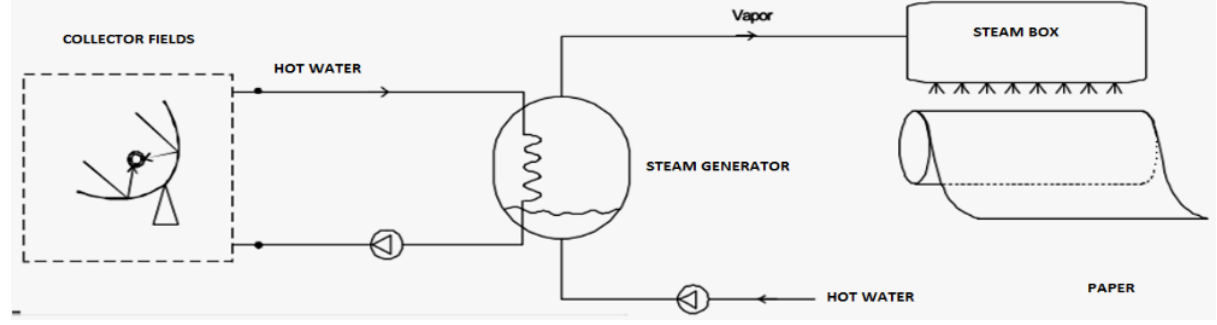

Figure 7. Paper drying from vapor 


\section{TECCIENCIA}

\subsection{Chemical industry}

In these industries (for example manufacture of cosmetic products) numerous processes exist requiring heating. For this, boilers are used to produce vapor yielded through heat exchangers to reservoirs to heat water or intermediate products; in other cases, vapor is used directly. In all cases, the vapor generated by the solar collectors can be used to heat the boilers (Figure 8).

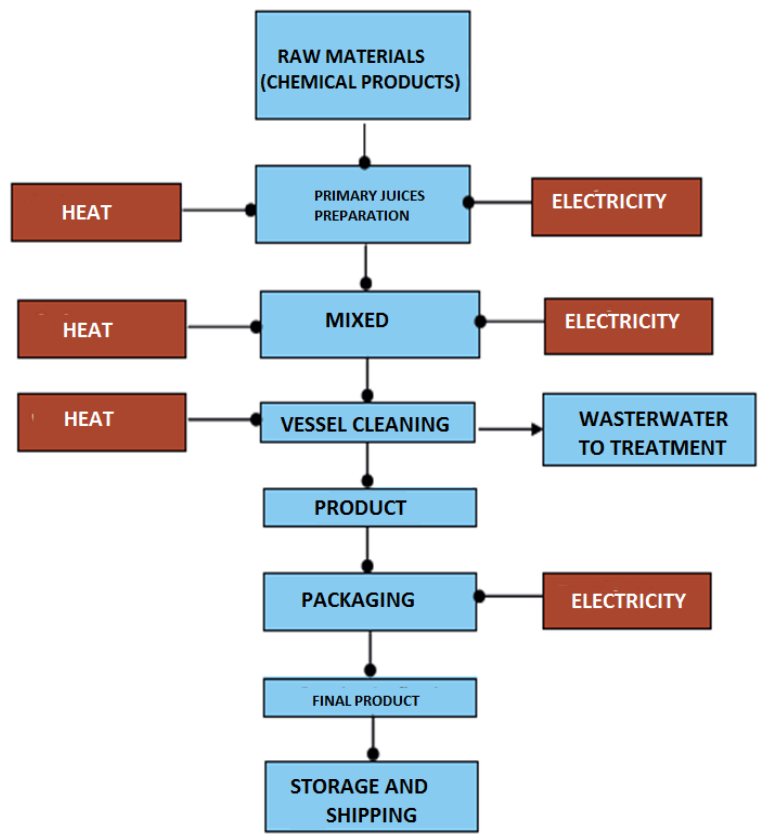

Figure 8. Manufacture of chemical products

\subsection{Desalination of water}

Many places exist like the Middle East and Africa that do not have enough water suitable for human consumption, even though they coastal zones with access to the sea. Some of these places have high levels of direct radiation and this has permitted the implementation of desalinating systems with solar technology to produce drinking water by desalinating sea water. Using solar systems to desalinate water requires large areas of land and it is not as efficient when compared to conventional systems (non-solar), but its low cost and ease of implementation make it one of the most promising technologies among the applications using direct radiation from the sun [14] [15]

Water desalination is achieved through successive stages. The device is composed of a closed container in which sea water is heated over $90{ }^{\circ} \mathrm{C}$ using a system of solar collectors that use direct radiation from the sun. The water vapor generated is taken to a cooling system (condenser) to condense it, thus, obtaining distilled water that is then stored in an adequate container. By evaporating the water separation of salt is achieved and water suitable for human consumption is obtained (Figure 9).

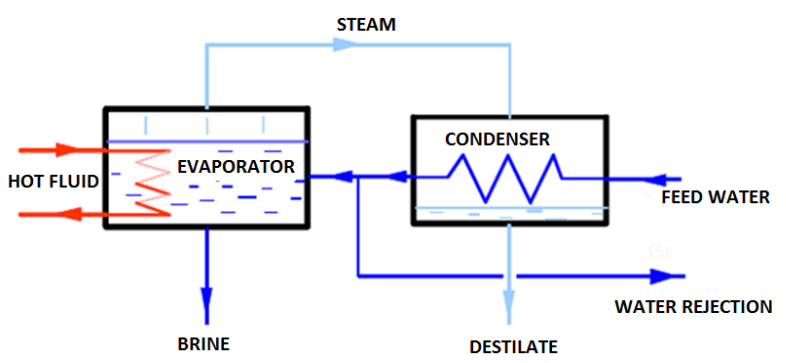

Figure 9. Operating scheme of water desalination

\subsection{Solar kitchen}

One of the most important uses employing the sun's direct energy by using collector systems is in cooking systems or solar kitchens. This has had great impact in India given the favorable radiation conditions and the population's economic needs. Projects with different capacities exist; some in which solar kitchens are developed for household uses and others developed for large projects for community use [16] [17] [18]

The solar kitchen shown in Figure 10 is located en Rajasthan, India and has 14 dish-type parabolic collectors, with $10 \mathrm{~m}^{2}$ of reflecting surface. This solar vapor cooking system was designed to generate $4000 \mathrm{~kg}$ of water vapor per day; sufficient to cook meals for 10,000 people. Additionally, the system has an oil boiler that guarantees its operation under all conditions [16]

At $1300 \mathrm{~m}$ above sea level, and when solar radiation peaks are reached on certain days, the system can provide approximately 38,500 meals. The structure produces temperatures of $650{ }^{\circ} \mathrm{C}$, which help to cook rice and vegetables in 200 - to 400 -liter pots.

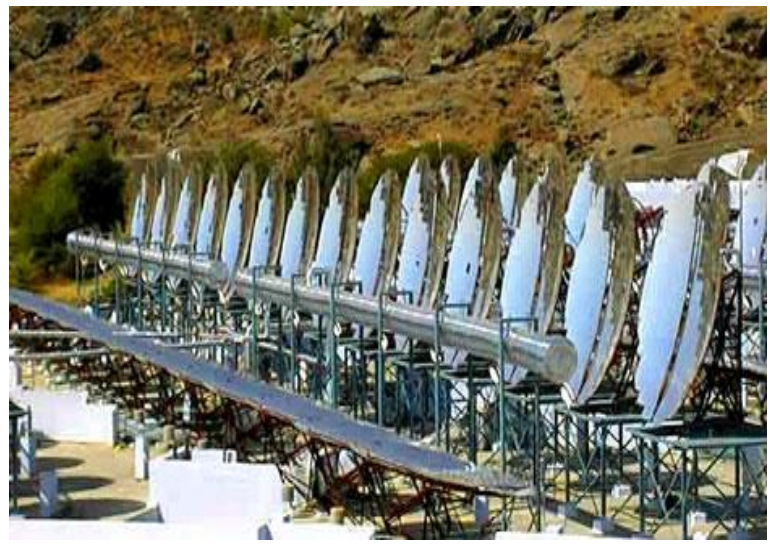

Figure 10. World's largest solar kitchen located in Rajasthan, India. Taken from: [16] 


\section{TECCIENCIA}

\subsection{Thermo-solar Centrals}

Development of thremo solar energy in the whole world depends on direct solar radiation, availability of land, and auxiliary services like water, gas, and electric networks.

Figure 11 illustrates the map of direct solar radiation in the world; note that Argeria, Australia, China, Egypt, Greece, India, Israel, Italy, Mexico, Morocco, Spain, and the United States are suitable places for the development of thermo-solar technologies.

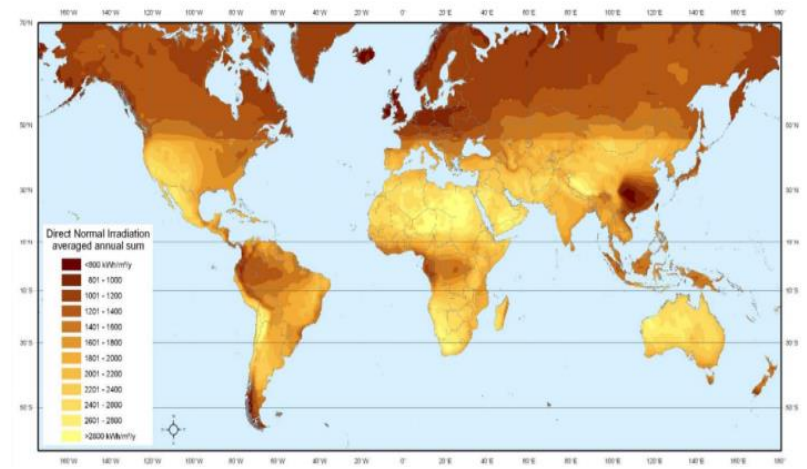

Figure 11. Multi-annual average of direct solar radiation in the world. [19]

Figure 12 shows that the development of thermo-solar technology is located mainly in the United States and Spain.

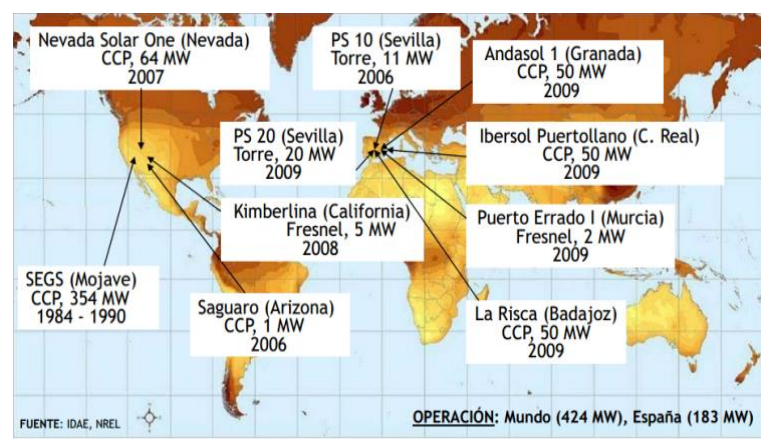

Figure 12. Thermo-solar projects in operation in the world. Taken from: [19] [20]

It is worth mentioning that other countries like Algeria (25 MW), Thailand (9.8 MW), and India (2.5 MW) permitted increasing the capacity connected to the network, reaching - in 2011 - a capacity of $1760 \mathrm{MW}$, with 23.8\% annual growth during 2001-2011 (Figure 13), where parabolic cylindrical collector centrals represent $90 \%$ of the plants in operation [20]

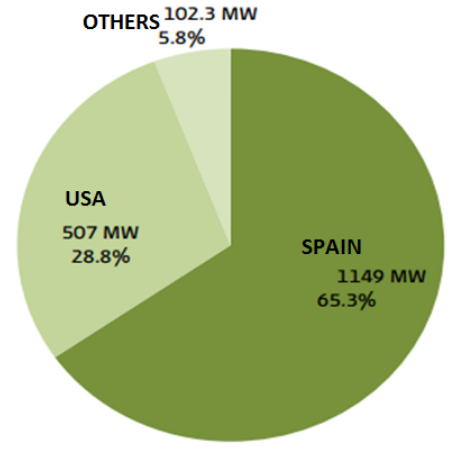

Figure 13. Installed capacity in thermo-solar plants [21]. Main countries (Spain and the United States)

Figure 14 presents the places and types of technology of the thermo-solar plants under construction, highlighting the plants located in California, like: Carrizo Energy Solar Farm and SES Solar Two, with a capacity of 177 and $300 \mathrm{MW}$, respectively. Studies conducted by GreenPace have evaluated the increase expected in installed power with thermo-solar technology for different penetration scenarios for the following years (until 2050), assuming that government policies will be in place to promote progress and use of this technology in every country.

The global power installed, projected under different scenarios for 2050 , could be $18,018 \mathrm{MW}$ in a low reference scenario; 830,707 MW in a moderate scenario; and 1,524,172 MW in an advanced scenario, bringing as a consequence a notable reduction in $\mathrm{CO}_{2}$ emissions for the environment, which could diminish emission to 5billion tons annually within an advanced scenario by 2050 [22]. Under these conditions, it is expected that the regions with the highest strengthening of the technology will be Europe, the United States, the Middle East, and China.

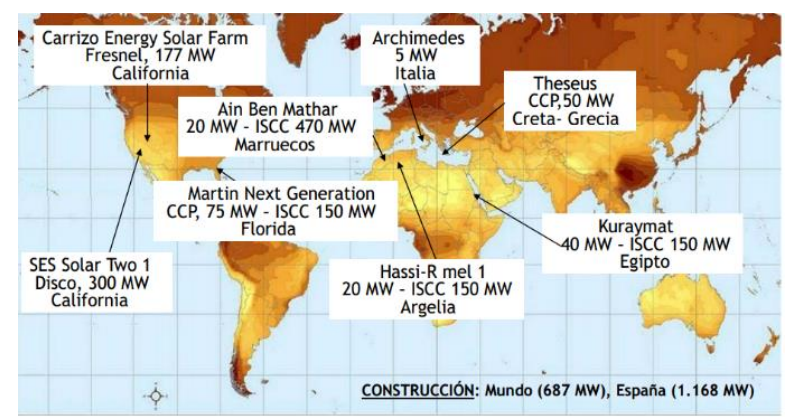

Figure 14. Thermo-solar plants under construction. Taken from: [19] [20]

Figure 15 shows the Shams 1 parabolic cylindrical plant, which has 100-MW capacity and permits providing energy to some 20,000 homes. The plant's solar park is 


\section{TECCIENCIA}

composed of 258,000 mirrors mounted on 768 parabolic cylindrical collectors, which concentrate the heat from the sun rays in tubes where synthetic oil circulates. The project includes a "dry refrigeration system that significantly reduces water consumption. The 192 rows of collectors of Shams 1 generate energy that avoids the emissions of 175,000 tons of $\mathrm{CO}_{2}$ per year, which is equivalent to removing 15,000 automobiles from circulation [23].

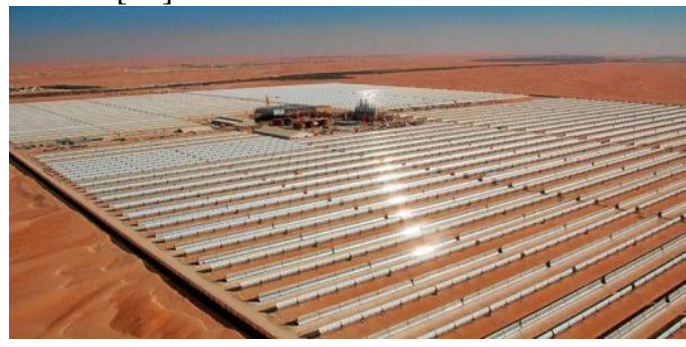

Figure 15. Shams 1 parabolic cylindrical plant, located in the Madinat Zayed dessert, United Arab Emirates.

[24]

\section{Conclusions}

Development of thermo solar energy depends on direct solar radiation, sun shine, availability of surface area, and auxiliary services like water, gas, and electric networks.

The places with highest interest for development of thermo solar technologies are the United States, Spain, India, China, Australia, North Africa, and the Middle East.

Thermo solar technologies are still a favorable option to combat the use of nonrenewable energy sources, like coal and petroleum derivates, contributing to $\mathrm{CO}_{2}$ reduction in the environment and associated costs.

Use and mass application of thermo solar technologies in industry is directly related to the type of process in which it is required and the degree of investment and development of the country's industry.

Although thermo solar systems have a vast number of applications in the industrial sector, electric energy production has most-influenced sector by these types of technologies.

\section{References}

[1] G. T. Machinda, S. P. Chowdhury, S. Chowdhury y S. Kibaara, «Concentrating Solar Thermal Power Technologies: A review,» de India Conference (INDICON), Hyderabad, 2011.
[2] D. Mills, «Advances in solat thermal electricity technology,» de Solar Energy, ELSEVIER, 2004, pp. 19-31.

[3] A. Steinfield y R. Palumbo, «Solar Thermochemical Process Technology,» de ENCYCLOPEDIA OF PHYSICAL SCIENCE \& TECHNOLOGY, R. A Meyers, Academic Press, 2001, pp. 237-256.

[4] G. I. eroga. [En línea]. Available: www.groupindustritaleroga.com/enersol/ .

[5] Gobierno de España. Ministerio de economia y competitividad, «Discos Parabolicos,» PSA, [En línea]. Available: http://www.psa.es/webesp/instalaciones/discos.php.

[6] Y. Zhang y B. Osbom, «Solar Dish-Stirling Power Plants and Related Grid Interconnection Issues,» de Power Engineering Society General Meeting, 2007. IEEE , 2007.

[7] F. Lupi, C. Borri, W. Kratzing y H. J. Nieman, «A Comparative Analysis of Energy Costs of Photovoltaic, Solar Thermal, and Wind Electricity Generation Technologies,» [En línea]. Available: http://www.eolss.net/sample-chapters/c08/E6-10643-00.pdf.

[8] «Tower solenergy,» [En línea]. Available: http://www.towersolenergy.com/TOWERSOL/gemasolarplant/en.

[9] Tubo Sol PE2, «Puerto Errado 2 - Die Zukunft der Solarthermie,» [En línea]. Available: http://www.puertoerrado2.com/.

[10] M. Wegelin y B. Sommer, «Solar water disinfection (SODIS), destined for worldwide use?,» Waterlines, vol. 16, nº 3, 1998.

[11] R. Chaudhari, M. M. Ahammed y S. Dave, «Solar disinfection of natural waters with modified solar concentrators,» Water Science \& Technology: Water Supply, vol. 13, n 2, pp. 462468, 2013

[12] H. Gómez, M. Fontán, P. Fernández y E. Ares, «Speeding up the solar water disinfection process (SODIS) against Cryptosporidium parvum by using 2.51 static solar reactors fitted with compound parabolic concentrators (CPCs),» Acta Tropica, vol. 124, n 3, pp. 235-242, 2012.

[13] J. Calle, J. Fajardo y L. Sánchez, «Agua caliente sanitaria de uso domestico con energia solar, una alternativa para la ciudad de cuenca,»INGENIUS, pp. 57-65.

[14] H. Mohameed y F. Banat, « Solar thermal desalination technologies,» Desalination Volume 220, Issues 1-3, vol. 220, $\mathrm{n}^{\mathrm{o}} 3$, pp. 633-644, 2008.

[15] L. Garzia-Rodriguez, «Seawater desalination driven by renewable energies: a review,» Desalination, vol. 143, $\mathrm{n}^{\circ} 2$, pp. 103-113, 2002.

[16] S. Muthu y R. Raman, «Concentrated paraboloid solar cookers for quantity cookery,» de Granada solar cooking conference, 2006.

[17] S. Muthu y R. Raman, «SGN Solar Energy, Payback Period With Different case studies,» [En línea]. Available: http://www.sgnsolar.com/payback-period.html.

[18] S. Mahavar, N. Sengar, M. Verma y P. Dashora, «Extensive Experimental Studies of a Single Family Solar Cooker,» International Journal of Energy, Information and Communications, vol. 2, no 4, 2011.

[19] Fundacion para estudios sobre la energia-, «Fundacion energia españa,» 29 October 2009. [En línea]. Available: http://www.fundacionenergia.es/PDFs/Solar\%20termo\%20elc trica\%201009/Situaci\%C3\%B3n\%20mundial\%20termosolar $\% 20291009$.pdf.

[20] REN 21, «Renewable Energy Policy Network for the 21st Century,» 2012. [En línea]. Available: http://www.ren21.net/ren21activities/globalstatusreport.aspx. 


\section{TECCIENCIA}

[21] Gobierno Federal, «Prospectiva de energías renovables 20122026,» Secretaria de energía, Mexico, 2012.

[22] Greenpeace, «Energía Solar Térmica de concentración,» California, 2009.

[23] F. Trieb, C. Schillings, M. O'Sullivan, T. Pregger y C. HoyerKlick, «Global Potential of Concentrating Solar Power,» de Solar Paces Conference, Berlin, 2009.

[24] G. Gómez, «Inaugurada la mayor planta de aprovechamiento de energía solar del mundo,»10 May 2013. [En línea].
Available:

http://www.madrimasd.org/blogs/energiasalternativas/2013/0 5/10/132022. 